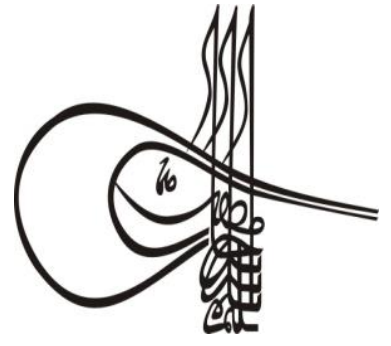

Received/Geliş: 06.08.2019

Gor Report Dates/Rapor Tarihleri: Referee 1 (16.08.2019)-Referee 2 (29.09.2019)

\section{Turkigl Studies Educational Sciences}

Volume 14 Issue 5, 2019, p. 2059-2076

DOI: 10.29228/TurkishStudies. 29353

ISSN: 2667-5609

Skopje/MACEDONIA-Ankara/TURKEY

Research Article / Araștırma Makalesi

Article Info/Makale Bilgisi

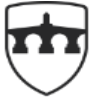

INTERNATIONAL BALKAN UNIVERSITY

EXCELLENCE FOR THE FUTURE IBU.EDU.MK

\Accepted/Kabul: 15.10 .2019

This article was checked by iThenticate.

\title{
TÜRKÇEYI YABANCI DİL OLARAK ÖĞRENEN SURİYELİ ÖĞRENCİLERİN YAZMA KAYGILARININ ÇEŞİTLİ DEĞİŞKENLER AÇISINDAN İNCELENMESI*
}

\author{
Yakup ALAN*
}

\begin{abstract}
ÖZ
Bu çalışmanın amac1; Türkçeyi yabancı dil olarak öğrenen Suriyeli öğrencilerin yazma kaygılarının çeşitli değişkenler açısından incelenmesidir. Araştırmada nicel ve nitel araștırma yöntemleri birlikte kullanılmıştır. Çalışmaya katılan öğrencilerin kişisel bilgilerini toplayabilmek için araştırmacı tarafından geliştirilen 9 maddelik "Kişisel Bilgi Formu" kullanılmıştır. Nicel araştırma yöntemi olarak tarama yöntemi seçilmiş ve Şen ve Boylu (2017) tarafından geliştirilen ve güvenirlik analizi yapılmış 13 maddelik likert tipi "Türkçeyi Yabancı Dil Olarak Öğrenenlere Yönelik Yazma Kaygısı Ölçeği” ile veriler elde edilmiştir. Nitel araştırma yönteminde ise olgubilim modeli seçilmiştir. Araştırmacı tarafından geliştirilmiş yarı yapılandırılmış görüşme formu kullanılmıs ve nitel veriler elde edilmiştir. Araştırmanın nicel kısmı uygun örnekleme yöntemine uygun olarak Kilis 7 Aralık Üniversitesi Türkçe ve Yabanc1 Diller Öğretimi Uygulama ve Araștırma Merkezinde C1 düzeyinde Türkçe öğrenen 123 Suriyeli öğrenciye (63 erkek, 60 kı) nitel kısmı ise örneklemden gönüllülük esasına dayalı olarak seçilen 27 öğrenciye uygulanmıştır. Araştırmada elde edilen nicel verilerin çözümlenmesinde SPSS 17.0 programı kullanılarak bağımsız örneklemler t-testi analizinden yararlanılmıștır. Nitel verilerin analizinde ise içerik analizinden yararlanılmış ve ortaya çıkan veriler öğrenci görüşleriyle desteklenmiştir. Araştırma sonucunda Türkçeyi yabancı dil olarak öğrenen Suriyeli öğrencilerin yazma kaygısı taşıdıkları ancak bu kayg1 düzeyinin yüksek olmadığı ve öğrencilerin Türkçe yazma çalışmalarına karşı olumlu bir bakış açısı sergiledikleri ortaya
\end{abstract}

*Bu çalışma; İCOTFL V. Uluslararası Yabancı Dil Olarak Türkçe Öğretimi Kongresi’nde sözlü bildiri olarak sunulmuştur.

** iD Öğr. Gör. Dr., Kilis 7 Aralık Üniversitesi, E-posta: alanyakup@ gmail.com 
çıkarılmıştır. Çalışmada ortaya çıkan sonuçların, yabancılara Türkçe öğretimi faaliyetlerine katkı sağlayacağı düşünülmektedir.

Anahtar Kelimeler: Yabancı Dil Olarak Türkçe, Suriyeli öğrenciler, Kayg1, Yazma Kaygis1.

\title{
ANALYZING THE WRITING ANXIETY OF SYRIAN STUDENTS WHO LEARN TURKISH AS A FOREIGN LANGUAGE IN TERMS OF SEVERAL VARIABLES
}

\begin{abstract}
The aim of this study is to analyze the writing concerns of Syrian students who learn Turkish as a foreign language in the terms of several variables. Quantitative and qualitative research methods were used together in the research. Personal Information Form en developed by the researcher was used to collect students' information. Scanning method was selected as quantitative research method and data was obtained with 13-item likert type "Writing Anxiety Scale for Those Who Learn Turkish as a Foreign Language" developed and analyzed for reliability by Şen and Boylu (2017) In the qualitative research method phenomenological method was selected. Qualitative data was obtained using a semistructured interview form developed by the researcher. The quantitative section of the research was applied to 123 Syrian students (63 male, 60 women) who learn $\mathrm{C} 1$ level Turkish in Kilis 7 Arallk University Turkish and Foreign Languages Teaching Application and Research Center and the qualitative section of it was applied to 27 students chosen on voluntary basis. Independent samples t-test analysis was used by using SPSS 17.0 program in the analysis of the quantitative data obtained from the study. Content analysis was used in qualitative data analysis. The results of the study were that Syrian students who learn Turkish as a foreign language experience writing anxiety but the level of that anxiety was not high and students display a positive view towards Turkish writing studies. The results of the study are thought to contribute to the activities of teaching Turkish to foreigners.
\end{abstract}

\section{STRUCTURED ABSTRACT}

\section{Introduction}

Writing, which is one of the skills of telling, can be defined in its most general form as the ability of individuals to express themselves in writing. According to Demirel and Şahinel (2006) writing means transferring feelings or thoughts by writing; and according to Göçer (2016), it is the process of transferring individuals' feelings or thoughts to paper. In language learning, gaining writing skills which is the last step of the natural sequence (listening, speaking, reading, writing) is very slow and difficult compared to other skills (Açık, 2008:.3; Bağc1 and Başar, 2013: 310; Erol, 2016: 183). Because writing skill contain many factors such as cognitive, affective and kinesthetic skills and consists of many factors such as having a good command of the grammar, legible 
writing, organizing what to write, creating a distinctive from, effective telling, having a rich vocabulary, knowing the features of the audience and knowing writing types (Güneyli, 2016: 164).

The slow and difficult development of writing skills compared to others brings with it many problems. Reasons such as sticking to the grammar rules, fear of making a mistake, inability to sort thoughts, undeveloped thought processes or the inability to sort them (Karatay, 2011:22) cause students to exhibit negative attitudes towards writing. One of these negative attitudes appears as writing anxiety.

Writing anxiety is the situation in which students avoid writing with the thought that they will be evaluated (İseri and Ünal, 2012: 69), and a reaction of individuals against writing (Zorbaz, 2011: 2272). Another definition is "the situation where an individual avoids writing with the thought that his or her writings will be evaluated". This reaction against writing is also physically manifested in the form of sadness, anger, fear emotionally or, at a more advanced level, in the form of various cramps in situations where writing is required such as a writing assignment, a writing activity in the class or writing a composition for exams (Daly and Wilson, 1983 cited Zorbaz, 2011: 2272). This reaction, which negatively affects the writing performances of individuals, can be seen at all levels of education (Tiryaki, 2012: 20).

\section{Method}

This study, which was prepared to examine the writing concerns of Syrian students who learn Turkish in terms of several variables, was designed as a mixed research. In this method, quantitative and qualitative research and the resulting data from them are combined and presented in a holistic manner (Creswell, 2013, p. 14). In this study too, quantitative and qualitative data were used together and a holistic approach was exhibited.

The universe of this research consists of foreign students learning Turkish in Kilis. The sample consists of 123 Syrian students at C1 level who learn Turkish at Kilis 7 Aralık University Turkish and Foreign Languages Teaching Application and Research Center (Kilis TÖMER). The convenience sampling method was preferred because of the ease of application in selecting the sample. This method can be applied by taking into account factors such as place and location in order to prevent the loss of time, money and labor (Marriam, 2013; Büyüköztürk et al., 2018: 95).

Personal Information Form, developed by the researcher to obtain personal information from students was used in the study. The form consists of 9 items and contains questions such as students' gender, age, the time they have lived in Turkey, the language they use when texting or online etc. "Writing Anxiety Scale for Those Who Learn Turkish as a Foreign Language", developed by Şen and Boylu (2017) was used in the study to measure the writing anxiety levels of Syrian students who learn Turkish. A semi-structured interview form was also used to gain students ' views on writing anxiety. The form prepared by the researcher was finalized by taking the opinions of the academicians who are experts in their fields. 
The data obtained by "Writing Anxiety Scale for Those Who Learn Turkish as a Foreign Language", which make up the quantitative data of the study were analyzed with SPSS 17.0 packaged software and unpaired t-test was made in analyzing variables. Content analysis was used in analyzing the qualitative data of the study, the data obtained from students' views were encoded and presented and interpreted as tables by categorizing. In order to ensure the security of the data, student views were also presented as examples.

\section{Conclusion and Discussion}

In this study, which aims to examine the writing anxieties of Syrian students who learn Turkish in terms of various variables, analyses were made in order to reveal students' levels of writing anxiety.

The analysis revealed that there is no significant difference in terms of students' anxieties about writing according to their gender, opinion on Turkish, extracurricular Turkish writing situations, the time they have spent in Turkey, the language they use online, in e-mails or when texting. When the effect of age factor on writing anxiety is examined, it can be seen that those who are 25 years of age or older have more anxiety than those who are younger. When the reading factor of Turkish magazines, books and newspapers was examined, it was found that the students who were reading were less worried than the ones who did not.

When the study is examined in general, it can be said that the writing anxiety of Syrian students learning Turkish is not high. $(\overline{\mathrm{X}}$ $=42,36$ ). The data obtained from the Student Interview Form, which collects the views of the students on writing skills, supports this result. According to the data obtained from the form, the majority of students feel happy and comfortable when writing in Turkish, they get help instead of letting go when they have difficulties in writing and they believe they can write an understandable and good Turkish composition. These results show that students do not have high levels of anxiety.

Although students stated that they do not have a high degree of writing anxiety, they also stated that the skill they are most challenged with is writing skill. Therefore, this skill should be given importance and activities that will improve students should be carried out in order to develop their writing skills and enable them to reach the desired level in this skill.

Keywords: Turkish as A Foreign Language, Syrian Students, Anxiety, Writing Anxiety.

\section{Giriş}

Dil öğretimi birçok unsurun birliktelik oluşturması sonucunda gerçekleşir. Bu birlikteliği meydana getiren unsurlardan biri de dil becerileridir. Anlama ve anlatma olmak üzere ikiye ayrılabilecek dil becerilerinde anlama becerileri okuma becerisi ve dinleme becerisi; anlatma becerileri de konuşma becerisi ve yazma becerisinden oluşmaktadır. İster ana dili öğretiminde isterse yabancı dil öğretiminde olsun, bu becerilerin tam kazanılması durumunda dil öğreniminin tamamlanmış olduğundan bahsedilebilir. 
Anlatma becerilerinden biri olan yazma becerisi, en genel haliyle; bireylerin kendilerini yazilı olarak ifade edebilmesi şeklinde tanımlanabilir. Demirel ve Şahinel'e (2006) göre de yazma; duygu veya düşünceyi yazı ile aktarma; Göçer'e (2016) göre ise bireylerin duygu veya düşüncelerini kâğıda aktarmasıdır. Dil öğreniminde doğal sıranın (dinleme, konuşma, okuma, yazma) en son basamağı olan yazma becerisinin kazanımı diğer becerilere göre oldukça yavaş ve zordur (Açık, 2008: 3; Bağcı ve Başar, 2013: 310; Erol, 2016: 183). Çünkü yazma becerisi içinde bilişsel, duyuşsal ve devinişsel beceriler gibi birçok unsuru barındırmaktadır ve dil bilgisine hâkim olma, okunaklı yazma, yazacaklarını düzenleyebilme, kendine özgü bir biçim oluşturabilme, etkili bir şekilde anlatabilme, zengin bir kelime hazinesine sahip olabilme, hitap edilecek kitlenin özelliklerini bilme ve yazı türlerini bilme gibi birçok unsurun da bir araya gelmesinden oluşmaktadır (Güneyli, 2016: 164).

Yazma bireylerin kendilerini ifade etmelerinin en kalıcı ve etkili yollarından biridir ve yaşamın her evresinde oldukça önemli bir yere sahiptir (Karakuş Tayşi ve Taşkın, 2018: 1174). Yazma becerisi gelişmiş bireylerin kendilerini ifade etme becerilerinin yüksek olduğu ve gelişmiş bir düşünce sistemiyle gözlem gücüne sahip oldukları (Özdemir ve Özbay, 2016: 274) da bilinen bir gerçektir.

\section{Yazma Kaygısı}

Yazma becerisinin diğer becerilere göre daha yavaş ve zor gelişmesi beraberinde birçok problemi getirmektedir. Yazma sürecinde dil bilgisi kurallarına bağlı kalma, hata yapma korkusu, düşünceleri sıralayamama, düşünce süreçlerinin gelişmemiş olması veya bunları sıralayamama (Karatay, 2011: 22) gibi sebepler öğrencilerin yazmaya karşı olumsuz tutumlar sergilemelerine neden olmaktadır. Bu olumsuz tutumlardan biri de yazma kaygısı olarak karşımıza çıkmaktadır.

Kişinin bir eylemi gerçekleştirirken kendisi ve gerçekleştireceği eylemle ilgili hissettiği korkuları ve o eylemle ilgili noksanlıkların hissederek kendisinden emin olamaması (Karahan, 2017: 3066) olarak tanımlanabilecek kaygı; genellikle geçici ve sürekli kaygı şeklinde karşımıza çıkmaktadır. Geçici kaygı, yerine getirilmeyen arzunun meydana gelmesiyle ortaya çıkar. Bu arzu gerçekleştiğinde devreden çıkar. Sürekli kaygının ortaya çıkmasıysa güvenliği tehlikeye düşürecek kapsamda bir ihtiyacın, bir olayın meydana gelmesiyle ve kısa sürede bu problemin ortadan kaldırılamamasıyla oluşmaktadır (İşeri ve Ünal, 2012: 68).

Yazma kaygısı ise öğrencilerin oluşturdukları metinlerin bir değerlendirmeye tabi tutulacağı ihtimaliyle yazmaktan korkması ve yazma sürecine girmemesidir (İşeri ve Ünal, 2012: 69) ve bireylerin; yazmaya karşı geliştirdikleri bir tepkidir (Zorbaz, 2011: 2272). Daly ve Wilson'a (1983: 327) göre "İnsanların, ortaya çıkardıkları metinlerin değerlendirmeye tabi tutulacağı fikriyle ortaya yazılı ürün çıkarmaktan korkması durumu"dur. Yazılı ürün oluşturmaya karşı gösterilen bu tepki; verilen ödev, derslerde yapılan çalışmalar ya da sınav maksadıyla kompozisyon oluşturma gibi yazmanın gerekli olduğu durumlarda üzüntü, kızgınlık, korku şeklinde duygusal olarak ya da daha ileri düzeyde, çeşitli krampların oluşması şeklinde de fiziksel olarak kendini gösterir (Daly ve Wilson, 1983'ten akt. Zorbaz, 2011: 2272). Öğrencilerin yazma başarılarını negatif etkileyen bu durum, eğitimin tüm aşamalarında karşımıza çıkabilir (Tiryaki, 2012: 20).

Yazma kaygısının ortaya çıkmasında birçok sebep vardır. Kılınç, Aytan ve Ünlü’ye (2016: 1516) göre bu sebepler; kişinin ortaya çıkardığı yazılı ürüne olumsuz eleştiriler yapılması, kişisel değerlendirme korkusu ve yazma derslerinde başarısızlık endişesi olarak verilebilir.

Kaygı altında yazmak, süreç içerisinde sürekli geri dönüp yazdıklarını tekrar gözden geçirmeye, önemsiz yerlere odaklanıp metnin tamamını gözden kaçırmaya, anlatımdaki tabiiliğin yok olmasına ve fikirlerin doğru ve eksiksiz şekilde ortaya koyulmasına engel olmaktadır. Bireylerin kaygı seviyeleri belli bir düzeyi aştığı zaman, düşüncelerini planlamada ve konuya yoğunlaşmada güçlük, dikkat dağınıklığı, yazmayı erteleme, yazmadan kaçınma gibi davranışlar geliştirdikleri gözlemlenmektedir (Karakuş Tayşi ve Taşkın, 2018: 1176). Bu nedenle öğrencilerin yazma kaygıları belli bir seviyede 
tutulmalıdır. Çünkü yazma kaygısı süreci her zaman olumsuz etkilemez. Tekindal'a göre (2009), belirli bir miktardaki kaygının güdüleyici bir etkisi vardır. Yine Yaman (2010: 272) da kaygının eğitim sürecinde iki farklı biçimde ortaya çıktığını ve birinin yazma becerisini olumsuz etkileyerek öğrenciyi yazmadan uzaklaştırdığını diğerinin ise, öğrenciyi güdüleyerek öğrenmeyi ve yazmayı kolaylaştırdığını belirtmiştir.

Orta düzeydeki yazma kaygısı bireyleri güdüleyerek onları yazmaya teşvik edebilecektir ve bu eğitim ortamlarında istenilen bir durumdur. Ancak yüksek düzeydeki yazma kaygısının öğrenci açısından birçok zararı bulunmaktadır. Reeves (1997: 38-39) yazma kaygısı yüksek olan bireylerde şu özelliklerin olduğunu söylemektedir:

- Bu bireylerin meslek seçiminde yazma becerisi etkili olmaktadır. Yazma becerisini gerektirmeyen meslekleri tercih etme eğilimi gösterirler.

- Eğitim hayatlarında da yazmayı gerektiren derslerden kaçma eğilimi gösterirler.

- Sınıf içinde de sınıf dışında da çok az yazı yazarlar.

- Yazma becerisi açısından hiç iyi bir model değillerdir.

- Sözel becerileri gerektiren testlerden ve okuduğunu anlamayı gerektiren testlerden oldukça düşük puanlar almaktadırlar.

Bireylerin hem eğitim hayatlarını hem de mesleki hayatlarını etkileyen ve çoğu zaman olumsuz durumların ortaya çıkmasına neden olan yazma kaygısının kontrol altına alınması ve bireyleri güdüleyecek düzeye indirilmesi gerekmektedir. Çünkü insanların bir dilin gerekliliklerini tam anlamıyla yerine getirebilmesi o dilin tüm becerilerini doğru ve etkili bir şekilde kullanabilmesi ile değerlendirilir (Karatay, 2011: 21). Bu anlamada bakıldığında yüksek yazma kaygısına sahip bireylerin yazma becerisinde gelişmeleri mümkün olmayacaktır. Dolayısıyla dile hâkimiyetleri de mümkün olmayacaktır.

\section{Yabancı Dil Olarak Türkçe Öğretiminde Yazma Kaygısı}

Türkçeyi yabancı dil olarak öğrenen öğrencilerin, bu süreçte yaşadıkları birçok problem bulunmaktadır. Er, Biçer ve Bozkırlı (2012: 59-60) yabancılara Türkçe öğretiminde karşılaşılan problemlere yönelik hazırlanmış olan çalışmaları inceledikleri araştırmalarında bu problemlerden bazılarını şu şekilde belirtmişlerdir: "Materyallerin eksikliği veya kullanılmamasından kaynaklanan sorunlar, derslere giren eğitmenlerle ilgili sorunlar, yabancılara Türkçe öğretimi programının olmayışıyla veya eksikliğiyle ilgili sorunlar, kaynak eksikliğinden kaynaklanan sorunlar, dil öğretim merkezleriyle ilgili sorunlar, eğitim ortamlarından kaynaklanan sorunlar, derslerde yararlanılan strateji yöntem ve tekniklerden kaynaklanan sorunlar, alfabe sorunları vb." Kirik de (2018) Arap öğrencilerle yaptı̆̆ çalışmada, Arap öğrencilerin Türkçe öğrenirken yaşadıkları sorunları şöyle sıralamıştır: "Fiziki ve sosyal sorunlar, yazma sorunları, okuma ve konuşma sorunları, dinleme-anlama ile ilgili sorunlar, okutmanlarla ilgili sorunlar." Karşılaşılan bu sorunlar Türkçenin yabancı dil olarak öğretilmesinde ve adayların Türkçeyi tam olarak öğrenmesinde büyük engeller teşkil etmektedir. Çünkü yabancılara Türkçe öğretmenin en temel amacı; Türkçe anlayabilen ve kendini Türkçe ifade edebilen bireyler yetiştirmektir. $\mathrm{Bu}$ amacın gerçekleşebilmesi için de bireylerin anlama becerilerinin ve anlatma becerilerinin tam anlamıyla gelişmiş olması gerekmektedir. Bu becerilerin hepsi birbiriyle bağlantılıdır ve bunlardan birinin eksikliği diğer becerileri de etkilemektedir. Türkçe öğrenen yabancı bireylerin en temel amacı da Türkçeyi tam öğrenerek iyi bir dil kullanıcısı olmaktır. Bu da sadece Türkçeyi tam edinmekle ve tüm becerilerde başarıya ulaşmakla sağlanabilir. Bu becerilerin arasında da yazma becerisinin dikkate alınması ve geliştirilmesi son derece önemlidir (Alan, 2019). Çünkü yabanc1 ögrencilerin yazma becerilerinin, özellikle üniversite eğitimlerinde, başarılarını etkilediği bilinen bir gerçektir (Büyükikiz, 2012: 71). Örneğin öğrencilerin derslerinde başarılı sayılabilmeleri için yeterli bilgiye sahip olup olmadıklarını ölçmede en çok kullanılan yollardan biri yazılı sınavdır. Yazma becerisi 
gelişmemiş bireylerin, bu sınavlarda istenen performansı göstermesi ise mümkün olamamaktadır (Alan, 2019: 1).

Dil becerileri gelişmemiş bireylerin anlama ve anlatma süreçlerinde kaygı yaşamaları kaçınılmaz bir durumdur. Bunun dışında da yabancı öğrencilerin girecekleri sınavlar ve bu sınavlar sonucunda değerlendirilecek olmaları da onların yaşadıkları kaygının diğer nedenleri olarak karşımıza çıkmaktadır (Polatcan, 2019: 206). Öğrencilerin yaşamış oldukları problemler ve kaygılar giderilmediği sürece yabancılara Türkçe öğretiminin amaçlarına ulaşılması, dolayısıyla da yazma becerilerinin geliştrilimesi mümkün olmayacaktır. Bu nedenle öğrencilerin yaşamış oldukları problemlerin ortaya çıkarılması ve buna yönelik çözüm önerilerinin sunulması amaca ulaşma noktasında büyük hizmet edecektir. Bu bağlamda, Türkçe öğrenen Suriyeli öğrencilerin yazma kaygılarının tespiti ve buna yönelik çözüm önerilerinin sunulması açısından bu çalışmanın da alana, bu alanda çalışma yapan araştırmacılara ve eğitimcilere yol göstereceği düşünülmektedir.

\section{Araştırmanın Amacı}

Bu çalışmada, Türkçe öğrenen Suriyeli öğrencilerin yazma kaygılarının çeşitli değişkenler açısından incelenmesi amaçlanmıştır. Bu doğrultuda, çalışmanın alt problemleri aşağıdaki şekilde belirlenmiştir:

1. Türkçe öğrenen Suriyeli öğrencilerin yazma kaygıları, cinsiyetlerine göre anlamlı bir farklıl1k göstermekte midir?

2. Türkçe öğrenen Suriyeli öğrencilerin yazma kaygıları yaşlarına göre anlamlı bir farklılık göstermekte midir?

3. Türkçe öğrenen Suriyeli öğrencilerin yazma kaygıları Türkçeye kolaylık ve zorluk açısından bakışlarına göre anlamlı bir farklılık göstermekte midir?

4. Türkçe öğrenen Suriyeli öğrencilerin yazma kaygıları Türkçe dergi, kitap, gazete okuma faaliyetleri yapıp yapmamalarına göre anlamlı bir farklılık göstermekte midir?

5. Türkçe öğrenen Suriyeli öğrencilerin yazma kaygıları ders dışı Türkçe yazma çalışmaları yapıp yapmamalarına göre anlamlı bir farkl1lık göstermekte midir?

6. Türkçe öğrenen Suriyeli öğrencilerin yazma kaygıları Türkiye'de geçirdikleri süreye göre anlamlı bir farkl11ık göstermekte midir?

7. Türkçe öğrenen Suriyeli öğrencilerin yazma kaygıları internette kullandıkları dile göre anlamlı bir farklılık göstermekte midir?

8. Türkçe öğrenen Suriyeli öğrencilerin yazma kaygıları e-posta yazarken kullandıkları dile göre anlamlı bir farkl1lık göstermekte midir?

9. Türkçe öğrenen Suriyeli öğrencilerin yazma kaygıları cep telefonlarında mesaj yazarken kullandıkları dile göre anlamlı bir farklılık göstermekte midir?

\section{Yöntem}

\section{Araştırma Modeli}

Türkçe öğrenen Suriyeli öğrencilerin yazma kaygılarının çeşitli değişkenler açısından incelenmesi amacıyla hazırlanan bu çalışma, karma bir araştırma olarak tasarlanmıştır. Kullanılan bu yöntemde nicel ve nitel araştırmalar ve bunlardan ortaya çıkan veriler birleştirilir ve bütüncül bir şekilde sunulur (Creswell, 2013, s. 14). Bu çalışmada da nicel ve nitel veriler birlikte kullanılmış ve bütüncül bir yaklaşım sergilenmiştir. 


\section{Evren ve Örneklem}

$\mathrm{Bu}$ araştırmanın evreni Kilis'te Türkçe öğrenen yabancı öğrencilerden oluşmaktadır. Örneklemini ise Kilis 7 Aralık Üniversitesi Türkçe ve Yabancı Diller Öğretimi Uygulama ve Araştırma Merkezinde (Kilis TÖMER) Türkçe öğrenen C1 düzeyindeki 123 (63 erkek, 60 k1z) Suriyeli öğrenci oluşturmaktadır. Örneklemin seçiminde uygulama kolaylığı nedeniyle uygun örnekleme yöntemi tercih edilmiştir. Zaman, para ve iş gücü kaybını önlemek amacıyla yer ve konum gibi faktörlerin dikkate alınmasıyla bu yönteme başvurulabileği çeşitli çalışmalarda (Marriam, 2013; Büyüköztürk vd., 2018: 95) dile getirilmiştir.

\section{Verilerin Toplanması}

Çalışmada öğrencilerin kişisel bilgilerini almak amacıyla araştırmacı tarafından geliştirilen Kişisel Bilgi Formu kullanılmıştır. 9 maddeden oluşan bu formda; öğrencilerin cinsiyeti, yaşı, Türkiye'de yaşadıkları süre, mesaj yazarken kullandıkları dil, internette kullandıkları dil gibi kişisel bilgilerini içeren sorular bulunmaktadır.

Çalışmada Türkçe öğrenen Suriyeli öğrencilerin yazma kaygılarının ölçülebilmesi amacıyla Şen ve Boylu (2017) tarafindan geliştirilen "Türkçeyi Yabancı Dil Olarak Öğrenenlere Yönelik Yazma Kaygısı Ölçeği” kullanılmıştır. Ölçek, hazırlayıcıları tarafından geçerlik ve güvenirlik analizleri yapılarak 13 maddelik ve beşli likert tipinde hazırlanmıştır. Ölçeğin Cronbach Alfa güvenirlik katsayısı .84 olarak belirlenmiştir (Şen ve Boylu, 2017: 1122). Bu araştırmada ise Cronbach Alfa güvenirlik katsayıs1 .77 olarak hesaplanmıştır.

Çalışmada öğrencilerin yazma kaygılarıyla ilgili görüşlerini alabilmek için de yarı yapılandırılmış görüşme formu kullanılmıştır. Araştırmacı tarafından hazırlanan forma, alanında uzman akademisyenlerin görüşü alınarak son hâli verilmiştir.

\section{Verilerin Analizi}

Çalıșmanın nicel verilerini oluşturan ve "Türkçeyi Yabancı Dil Olarak Öğrenenlere Yönelik Yazma Kaygısı Ölçeği” ile elde edilen veriler SPSS 17.0 paket programılla analiz edilmiştir. Ölçekte yer alan olumlu maddeler "kesinlikle katılmıyorum" seçeneğinden "kesinlikle katıliyorum" seçeneğine doğru 5, 4, 3, 2, 1; olumsuz maddeler ise ters yönde 1, 2, 3, 4, 5 şeklinde puanlanmıştır.

Verilerin normallik dağılımlarını belirleyebilmek için Kolmogorov-Smirnov testi uygulanmış ve verilerin normal dağılım gösterdiği belirlenmiştir. Bu nedenle de parametrik testlerin kullanılmasına karar verilmiştir. Değişkenlerin analizinde bağımsız örneklemler t-testi yapılmıştır.

Çalışmanın nitel verilerinin çözümlenmesinde ise içerik analizi kullanılmıştır. $\mathrm{Bu}$ analiz çeşidinde, ilgili veriler belirli tema ve kavramlar çerçevesinde birlikte verilir ve okuyucunun anlayabileceği bir şekilde yorumlanır (Yıldırım ve Şimşek, 2016). Buna göre öğrenci görüşlerinden hareketle ortaya çıkan veriler kodlanmış, kategorilere ayrılarak tablolar hâlinde verilmiş ve yorum yapılmıştır. Verilerin güvenirliğini sağlamak amacıyla katılımcıların görüşleri de örnek olarak sunulmuştur.

\section{Bulgular}

\section{Nicel Bulgular}

Cinsiyet değişkenine göre Türkçe öğrenen Suriyelilerin yazma kaygıları arasında anlamlı bir farklılık olup olmadığını anlamak maksadıyla bağımsız t testi uygulanmıştır. Analiz sonuçları Tablo 1'de gösterilmiştir. 
Tablo 1: Öğrencilerin Cinsiyet Değişkenine Göre Yazma Kaygılarına Yönelik Tutumlarının T-Testi Sonuçları

\begin{tabular}{cccccc}
\hline Cinsiyet & N & $\begin{array}{c}\text { Aritmetik } \\
\text { Ortalama }\end{array}$ & $\begin{array}{c}\text { Standart } \\
\text { Sapma }\end{array}$ & t & p \\
\hline Erkek & 63 & 42,06 & 5,55 &, 469 &, 640 \\
K1z & 60 & 42,68 & 8,67 & & \\
\hline
\end{tabular}

Türkçe öğrenen Suriyelilerin cinsiyet değişkenine göre yazma kaygılarına yönelik tutumlarının puanları arasındaki farka ait $\mathrm{t}$ değeri $(\mathrm{t}=, 469 \mathrm{p}>0.05)$ anlamlı bulunmamıştır. Bu bulgu Türkçe öğrenen Suriyelilerin cinsiyet değişkenine göre yazma kaygılarına yönelik tutumları arasında anlamlı bir farklılık olmadığını ortaya çıkarmaktadır.

Tablo 1'e bakıldığında kızların yazma kaygılarına yönelik tutumlarının aritmetik ortalamasının $(\bar{X}=42,68)$ erkeklerinkinden $(\bar{X}=42,06)$ büyük olduğu görülmesine rağmen anlamlı bir farklılık oluşturmadığı söylenebilir.

Yaş değişkenine göre Türkçe öğrenen Suriyelilerin yazma kaygıları arasında anlamlı bir farklılık olup olmadığını ortaya çıkarmak için bağımsız t testi uygulanmıştır.

Tablo 2: Öğrencilerin Yaş Değişkenine Göre Yazma Kaygılarına Yönelik Tutumlarının T-Testi

\begin{tabular}{cccccc}
\multicolumn{8}{c}{ Sonuçları } \\
\hline Yaş & N & $\begin{array}{c}\text { Aritmetik } \\
\text { Ortalama }\end{array}$ & $\begin{array}{c}\text { Standart } \\
\text { Sapma }\end{array}$ & t & p \\
\hline $18-24$ & 98 & 41,68 & 7,48 &, 481 &, 040 \\
25 ve üstü & 25 & 45 & 5,94 & & \\
\hline
\end{tabular}

Tablo 2'de öğrencilerin yaş değişkenine göre yazma kaygıları arasında fark olup olmadığına yönelik t-testi sonuçları verilmiştir. Buna göre Türkçe öğrenen Suriyelilerin yaş değişkenine göre yazma kaygılarına yönelik tutumlarının puanları arasındaki farka ait $t$ değeri $(\mathrm{t}=, 481 \mathrm{p}<0.05)$ anlamlı bulunmuştur. Bu bulgulara göre Türkçe öğrenen Suriyelilerin yaş değişkenine göre yazma kaygılarına yönelik tutumları açısından 25 yaş ve üstündeki öğrencilerin yazma bakımından daha fazla kaygı duyduklarını söylemek mümkündür.

$\mathrm{Bu}$ sonuçların ortaya çıkmasında 24 yaş altındaki öğrencilerin lise eğitimlerini de Türkiye'de almaları ve Türkçe derslerine de girmelerinin etkili olduğunu söylemek mümkündür. Lise eğitimlerinde görmüş oldukları Türkçe dersleri daha az kaygı duymalarını sağlamıştır.

Öğrencilerin Türkçe öğrenmeye zorluk ve kolaylık açısından bakma durumları değişkenine göre yazma kaygıları arasında anlamlı bir farklılık olup olmadığını ortaya çıkarmak için bağımsız $\mathrm{t}$ testi uygulanmıştır

Tablo 3: Öğrencilerin Türkçeye Bakış Açıları Değişkenine Göre Yazma Kaygılarına Yönelik Tutumlarının T-Testi Sonuçları

\begin{tabular}{cccccc}
\hline $\begin{array}{c}\text { Türkçe Öğrenmek Zor } \\
\text { mu? }\end{array}$ & $\mathbf{N}$ & $\begin{array}{c}\text { Aritmetik } \\
\text { Ortalama }\end{array}$ & $\begin{array}{c}\text { Standart } \\
\text { Sapma }\end{array}$ & $\mathbf{t}$ & $\mathbf{p}$ \\
\hline Evet & 52 & 40,92 & 7,12 &, 228 &, 060 \\
Hayır & 71 & 43,42 & 7,29 & & \\
\hline
\end{tabular}

Tablo 3'e göre Türkçe öğrenen Suriyelilerin Türkçe öğrenmeye karşı bakış açıları değişkenine göre yazma kaygılarına yönelik tutumlarının puanları arasındaki farka ait $t$ değeri $(t=, 228$ 
p>0.05) anlamlı bulunmamıştır. Bu bulgular öğrencilerin Türkçe öğrenmeyi zor ya da kolay olarak görmelerinin yazma kaygıları üzerinde bir etkisinin olmadığını göstermektedir.

Tablo 3 incelendiğinde Türkçe öğrenmek kolaydır diyen öğrencilerin yazma kaygılarına yönelik tutumlarının aritmetik ortalamasının $(\bar{X}=43,42)$ Türkçe öğrenmek zordur diyen öğrencilerinkinden ( $\overline{\mathrm{X}}=40,92$ ) büyük olduğu görülmesine rağmen bu sonucun anlamlı bir farklılık ortaya çıkarmadığı görülmektedir.

Öğrencilerin Türkçe kitap, gazete okuma durumları değişkenine göre yazma kaygıları arasında anlamlı bir farklılık olup olmadığını ortaya çıkarmak için bağımsız $t$ testi uygulanmıştır.

Tablo 4: Öğrencilerin Türkçe Kitap, Gazete Okuma Durumları Değişkenine Göre Yazma Kaygılarına Yönelik Tutumlarının T-Testi Sonuçları

\begin{tabular}{cccccc}
\hline $\begin{array}{c}\text { Türkçe Kitap, Gazete } \\
\text { Okuyor musunuz? }\end{array}$ & $\mathbf{N}$ & $\begin{array}{c}\text { Aritmetik } \\
\text { Ortalama }\end{array}$ & $\begin{array}{c}\text { Standart } \\
\text { Sapma }\end{array}$ & $\mathbf{t}$ & $\mathbf{p}$ \\
\hline Evet & 67 & 44 & 6,78 &, 838 &, 050 \\
Hayır & 56 & 40,56 & 7,75 & & \\
\hline
\end{tabular}

Tablo 4'te öğrencilerin Türkçe kitap, gazete okuma durumları değişkenine göre yazma kaygıları arasında anlamlı bir farklılık olup olmadığına yönelik t-testi sonuçları verilmiştir. Buna göre Türkçe öğrenen Suriyelilerin Türkçe kitap, gazete okuma durumları değişkenine göre yazma kaygılarına yönelik tutumlarının puanları arasındaki farka ait t değeri $(\mathrm{t}=, 838 \mathrm{p} \leq 0.05)$ anlamlı bulunmuştur. $\mathrm{Bu}$ bulgulara göre Türkçe öğrenen Suriyelilerden Türkçe kitap ve gazete okuyanların lehine anlamlı bir farklılık ortaya çıktığını söylemek mümkündür.

Tablo incelendiğinde Türkçe kitap ve dergi okuyan öğrencilerin yazma kaygılarına yönelik puanlarının aritmetik ortalamasının (=44) Türkçe okuma yapmayan öğrencilerin aritmetik ortalamasından $(=40,56)$ büyük olduğu ve bu büyüklüğün anlamlı bir fark ortaya çıkardığı görülmektedir.

Öğrencilerin Türkçe kompozisyon, şiir, hikâye yazma durumları değişkenine göre yazma kaygıları arasında anlamlı bir farklılık olup olmadığını ortaya çıkarmak için bağımsız t testi uygulanmıştır.

Tablo 5: Öğrencilerin Türkçe Kompozisyon, Şiir, Hikâye Durumları Değiş̧kenine Göre Yazma Kaygılarına Yönelik Tutumlarının T-Testi Sonuçları

\begin{tabular}{cccccc}
\hline $\begin{array}{c}\text { Türkçe Kompozisyon, } \\
\text { Şiir, Hikâye Yazyyor } \\
\text { musunuz? }\end{array}$ & $\mathbf{N}$ & $\begin{array}{c}\text { Aritmetik } \\
\text { Ortalama }\end{array}$ & $\begin{array}{c}\text { Standart } \\
\text { Sapma }\end{array}$ & $\mathbf{t}$ & $\mathbf{p}$ \\
\hline Evet & 38 & 42,21 & 8,92 &, 135 &, 875 \\
Hayır & 85 & 42,43 & 6,49 & & \\
\hline
\end{tabular}

Tablo 5'e göre Türkçe öğrenen Suriyelilerin yazma dersi dışında Türkçe yazma çalışmaları yapma durumları değişkenine göre yazma kaygılarına yönelik tutumlarının puanları arasındaki farka ait $\mathrm{t}$ değeri $(\mathrm{t}=, 135 \mathrm{p}>0.05)$ anlamlı bulunmamıştır. Bu bulgular öğrencilerin ders dişında yaptıkları yazma çalışmalarının yazma kaygısı üzerinde anlamlı bir farklılık ortaya çıkarmadığını göstermektedir. Bunun nedeni olarak da öğrencilerin ders dışı yazma çalışmalarını genellikle ödevlerini yapma şeklinde gerçekleştirmeleri olarak görülebilir. Ödev yapmayı bir zorunluluk olarak hissetmeleri ve bu çalışmaları isteyerek değil de zorunlu olarak yapmaları onların kaygılarında herhangi bir azalma oluşturmamaktadır. 
Öğrencilerin Türkiye'de yaşadıkları süre değişkenine göre yazma kaygıları arasında anlamlı bir farklılık olup olmadığını ortaya çıkarmak için bağımsız t testi uygulanmıştır.

Tablo 6: Öğrencilerin Türkiye’de Yaşadıkları Süre Değişkenine Göre Yazma Kaygılarına Yönelik Tutumlarının T-Testi Sonuçları

\begin{tabular}{cccccc}
\hline $\begin{array}{c}\text { Ne Zamandır } \\
\text { Türkiye'de } \\
\text { Yaşıorsunuz? }\end{array}$ & N & $\begin{array}{c}\text { Aritmetik } \\
\text { Ortalama }\end{array}$ & $\begin{array}{c}\text { Standart } \\
\text { Sapma }\end{array}$ & $\mathbf{t}$ & $\mathbf{p}$ \\
\hline 1 yıl & 22 & 43,90 & 7,60 &, 947 &, 309 \\
1 yıldan fazla & 101 & 42,11 & 7,23 & & \\
\hline
\end{tabular}

Tablo 6'da Türkçe öğrenen Suriyelilerin Türkiye'de yaşadıkları sürenin yazma kaygılarını etkilemesine yönelik sonuçlar verilmiştir. Bu sonuçlara göre öğrencilerin yazma kaygılarına yönelik tutumlarının puanları arasındaki farka ait $\mathrm{t}$ değeri $(\mathrm{t}=, 947 \mathrm{p}>0.05)$ anlamlı bulunmamıştır. Bu bulgular öğrencilerin Türkiye'de geçirdikleri sürenin yazma kaygısı üzerinde anlamlı bir farklılık ortaya çıkarmadığını göstermektedir. Aslında kaygı üzerinde önemli olması beklenen bu değişkenin kaygıyı azaltmama nedeni olarak bu öğrencilerin yaşadıkları çevre gösterilebilir. Bu öğrencilerin çok yoğun Suriyeli nüfusun içinde yaşıyor olmaları ve hem sosyal çevrelerinde hem de diğer ihtiyaçlarını gidermede Arapça kullanıyor olmaları onların Türkçeye ihtiyaç duymamalarına neden olmaktadır. Sadece TÖMER'de Türkçe kullanan bu öğrencilerin Türkiye'de geçirdikleri süre de bu nedenlerle yazma kaygıları üzerinde etkili olamamıştır.

Öğrencilerin internet sitelerinde kullandıkları dil değişkenine göre yazma kaygıları arasında anlamlı bir farklılık olup olmadığını ortaya çıkarmak için bağımsız t testi uygulanmıştır.

Tablo 7: Öğrencilerin İnternet Sitelerinde Kullandıkları Dil Değişkenine Göre Yazma Kaygılarına Yönelik Tutumlarının T-Testi Sonuçları

\begin{tabular}{cccccc}
\hline $\begin{array}{c}\text { Internette Genellikle } \\
\text { Hangi Dili } \\
\text { Kulanıyorsunuz? }\end{array}$ & N & $\begin{array}{c}\text { Aritmetik } \\
\text { Ortalama }\end{array}$ & $\begin{array}{c}\text { Standart } \\
\text { Sapma }\end{array}$ & t & p \\
\hline Türkçe & 37 & 44,21 & 6,88 &, 818 &, 065 \\
Arapça & 86 & 41,56 & 7,36 & & \\
\hline
\end{tabular}

Tablo 7'de öğrencilerin internette kullandıkları dil değişkenine göre yazma kaygıları arasında anlamlı bir farklılık olup olmadığına yönelik t-testi sonuçları verilmiştir. Buna göre Türkçe öğrenen Suriyelilerin internette kullandıkları dil değişkenine göre yazma kaygılarına yönelik tutumlarının puanları arasındaki farka ait $\mathrm{t}$ değeri $(\mathrm{t}=, 818 \mathrm{p}>0.05)$ anlamlı bulunmamıştır. Bu bulgulara göre Türkçe öğrenen Suriyelilerin internette kullandıkları dilin yazma kaygısını etkilemediği söylenebilir.

Tablo incelendiğinde internet dili olarak Türkçe kullanan öğrencilerin yazma kaygılarına yönelik puanlarının aritmetik ortalamasının $(=44,21)$ internet dili olarak Arapça kullanan öğrencilerin aritmetik ortalamasından $(=41,56)$ büyük olduğu ancak bu büyüklüğün anlamlı bir fark ortaya çıkarmadığı görülmektedir.

Öğrencilerin e-posta yazarken kullandıkları dil değişkenine göre yazma kaygıları arasında anlamlı bir farklılık olup olmadığını ortaya çıkarmak için bağımsız t testi uygulanmıştır. 
Tablo 8: Öğrencilerin E-Posta Yazarken Kullandıkları Dil Değişkenine Göre Yazma Kaygılarına Yönelik Tutumlarının T-Testi Sonuçları

\begin{tabular}{cccccc}
\hline $\begin{array}{c}\text { E-posta Yazarken } \\
\text { Genellikle Hangi Dili } \\
\text { Kulanıorsunuz? }\end{array}$ & N & $\begin{array}{c}\text { Aritmetik } \\
\text { Ortalama }\end{array}$ & $\begin{array}{c}\text { Standart } \\
\text { Sapma }\end{array}$ & t & p \\
\hline Türkçe & 46 & 42,47 & 8,06 &, 170 &, 896 \\
Arapça & 77 & 42,29 & 6,85 & & \\
\hline
\end{tabular}

Tablo 8'de Türkçe öğrenen Suriyelilerin e-posta yazarken kullandıkları dilin yazma kaygılarını etkilemesine yönelik sonuçlar verilmiştir. Bu sonuçlara göre öğrencilerin yazma kaygılarına yönelik tutumlarının puanları arasındaki farka ait t değeri $(\mathrm{t}=, 170 \mathrm{p}>0.05)$ anlamlı bulunmamıştır. Bu bulgular öğrencilerin e-posta yazarken kullandıkları dilin yazma kaygısı üzerinde anlamlı bir farklılık ortaya çıkarmadığını göstermektedir. Öğrencilerin e-posta yazma amaçları dikkate alındığında, bu öğrencilerin e-postaları da zorunlu nedenlerden dolayı Türkçe yazmalarının, kaygı üzerinde etkili olmamasına neden olduğu söylenebilir. Öğrenciler bu kaynağı da kendi istekleri doğrultusunda Türkçe kullanmamaktadır. Burs, ders kaydı gibi nedenlerden dolayı zorunlu olarak Türkçe e-posta atmaktadırlar.

Öğrencilerin cep telefonlarında mesaj yazarken kullandıkları dil değişkenine göre yazma kaygıları arasında anlamlı bir farklılık olup olmadığını ortaya çıkarmak için bağımsız $t$ testi uygulanmiştır.

Tablo 9: Öğrencilerin Cep Telefonlarında Mesaj Yazarken Kullandıkları Dil Değişkenine Göre Yazma Kaygılarına Yönelik Tutumlarının T-Testi Sonuçları

\begin{tabular}{cccccc}
\hline $\begin{array}{c}\text { Cep Telefonunuzda } \\
\text { Mesaj Yazarken } \\
\text { Genellikle Hangi Dili } \\
\text { Kulanıyorsunuz? }\end{array}$ & N & $\begin{array}{c}\text { Aritmetik } \\
\text { Ortalama }\end{array}$ & $\begin{array}{c}\text { Standart } \\
\text { Sapma }\end{array}$ & $\mathbf{t}$ & $\mathbf{p}$ \\
\hline Türkçe & 30 & 42,56 & 8,58 &, 329 &, 863 \\
Arapça & 93 & 42,30 & 6,88 & & \\
\hline
\end{tabular}

Tablo 9'da Türkçe öğrenen Suriyelilerin cep telefonlarında mesaj yazarken kullandıkları dilin yazma kaygılarını etkilemesine yönelik sonuçlar verilmiştir. Bu sonuçlara göre öğrencilerin yazma kaygılarına yönelik tutumlarını puanları arasındaki farka ait $t$ değeri $(t=, 329 \mathrm{p}>0.05)$ anlamlı bulunmamıştır. Bu bulgular öğrencilerin cep telefonlarında mesaj yazarken kullandıkları dilin yazma kaygısı üzerinde anlamlı bir farklılık ortaya çıkarmadığını göstermektedir.

\section{Nitel Bulgular}

\section{Öğrencilerin Türkçe Yazı Yazmaya ve Yazma Kaygısına Yönelik Görüşleri}

Tablo 10: Öğrencilerin Türkçe Yazı Yazarken Hissettiklerine Yönelik Veriler

\begin{tabular}{|c|c|c|}
\hline \multicolumn{3}{|c|}{ Türkçe Yazı Yazdığınızda Neler Hissediyorsunuz? } \\
\hline Madde & Frekans & Öğrenci \\
\hline Mutlu oluyorum & 16 & $\begin{array}{l}\text { Ö-2, Ö-3, Ö-4, Ö-5, Ö-7, Ö-9, Ö- } \\
\text { 11, Ö-14, Ö-15, Ö-16, Ö-19, Ö- } \\
\text { 20, Ö-22, Ö-24, Ö-25, Ö-27 }\end{array}$ \\
\hline Rahat hissediyorum & 4 & Ö-9, Ö-11, O- $15, \ddot{O}-19$ \\
\hline Hiçbir şey hissetmiyorum & 5 & Ö-17, Ö-18, Ö-21, Ö-23, Ö-26 \\
\hline Rahat hissetmiyorum & 1 & Ö-1 \\
\hline Sikıliyorum & 4 & Ö-4, Ö-6, Ö-8, Ö-10 \\
\hline Yorgun hissediyorum & 3 & Ö-8, Ö-10, Ö-17 \\
\hline Normal hissediyorum & 2 & Ö-12, Ö-13 \\
\hline
\end{tabular}


Tablo 10'da Türkçe öğrenen Suriyeli öğrencilerin Türkçe yazı yazarken neler hissettiklerine dair görüşleri verilmiştir. Buna göre öğrencilerin çok büyük kısmının Türkçe yazı yazarken mutlu (f= 16) olduğu görülmektedir. Bunun dışında da 4 öğrenci de Türkçe yazı yazarken kendilerini rahat hissettiklerini belirtmişlerdir. Türkçe yazı yazarken rahat olmayan veya sıkılan öğrenci sayısı ise 5'tir. $\mathrm{Bu}$ sonuçlara göre Türkçe öğrenen Suriyeli öğrencilerin Türkçe yazı yazarken kendilerini iyi hissettikleri söylenebilir. Buna yönelik öğrenci görüşlerinden bazıları şöyledir:

Türkçe yazı yazdlğımda fikirler her zaman arapça geliyorlar buyüzden rahat hissetmiyorum $(\ddot{O}-1)$

Ben Türkçe yazı yazdığımda biraz sıkllırım Çünkü ben yazar değilim ve yazmam'da biraz sıkıntı var (̋̈-6)

Mutlu ve rahat hissediyorum (Ö-11)

Normal hissediyorum (Ö-12)

Türkçe yazı yazdığımda kendimi mutlu hissidiyorum (Ö-14)

Hiçbir şey hissetmiyorum sadece ellerim ağriyor (Ö-17)

Türkçe öğrenen Suriyeli öğrencilerin yazma becerileri açısından kendilerine olan inançlarına yönelik veriler Tablo 11'de verilmiştir.

Tablo 11: Öğrencilerin Anlaşı1ır Bir Şekilde Türkçe Kompozisyon Yazıp Yazamayacaklarına Dair İnançlarına Yönelik Veriler

\begin{tabular}{lcc}
\hline \multicolumn{2}{l}{ Güzel ve Anlaşılır Bir Șekilde Türkçe Kompozisyon Yazacağınıza İnanıyor musunuz? Neden? } \\
\hline Madde & Frekans & Ögrenci \\
\hline İnanıyorum & 18 & Ö-2, Ö-5, Ö-7, Ö-8, Ö-9, Ö-10, Ö- \\
& & 11, Ö-12, Ö-13, Ö-15, Ö-16, Ö- \\
& & 19, Ö-20, Ö-22, Ö-23, Ö-24, Ö-25 \\
İnanmiyorum & 6 & Ö-1, Ö-4, Ö-14, Ö-17, Ö-26, Ö-27 \\
Yorum yok & 3 & Ö-3, Ö-6, Ö-18 \\
\hline
\end{tabular}

Tablo 11'e bakıldığında öğrencilerin çok büyük kısmının Türkçe kompozisyon yazabileceklerine dair görüş bildirdiği görülmektedir. İyi bir Türkçe öğrenim süreci geçirdiklerine dair görüşleri ve kendilerine olan inançları öğrencilerin bu verilerin ortaya çıkarmasını sağlamıştır. Aynı şekilde bu veriler öğrencilerin Türkçe yazı yazmaya karşı yüksek güdüye sahip olduklarının da bir göstergesi olarak görülebilir. Maddeye ilişkin öğrenci görüşlerinden bazıları şöyledir:

19)

Güzel bir kompozisyon yazarım. Çünkü ben iyi bir şekilde Türkçe öğreniyorum (Ö-

Evet inaniyorum $(\ddot{O}-20)$

Evet, ben Türkçe kompozisyon yazacağım inaniyorum. Çünkü ben Türkçeye çok hoşlanıyorum $(\ddot{O}-21)$

Evet inaniyorum çünkü ben her şeyi iyi bir şekilde öğrendim. (Ö-22)

Hayır Sanmıyorum. Çünkü henüz dil ögrenmeyi tamamlamadım. (Ö-26)

( $\ddot{O}-27)$

Elbette hayır. Çünkü bu benim dilim değil belki Arapça kompozisyon yazabilirim.

Öğrencilerin Türkçe yazı yazarken zorlandıklarında ne yaptıklarıyla ilgili veriler Tablo 12'de verilmiştir. 
Tablo 12: Suriyeli Öğrencilerin Türkçe Yazma Çalışması Esnasında Zorlandıklarında Neler Yaptıklarına İlişkin Veriler

\begin{tabular}{|c|c|c|}
\hline \multicolumn{3}{|c|}{ Türkçe Yazı Yazarken Zorlandığınızda Ne Yapıyorsunuz? } \\
\hline Madde & Frekans & Öğrenci \\
\hline Sözlüğe bakıyorum & 10 & $\begin{array}{l}\text { Ö-1, Ö-2, Ö-15, Ö-16, Ö-18, Ö- } \\
\text { 19, Ö-20, Ö-21, Ö-26, Ö-27 }\end{array}$ \\
\hline İnternetten yararlanıyorum & 11 & $\begin{array}{l}\text { Ö-4, Ö-12, Ö-13, Ö-14, Ö-15, Ö- } \\
16 \text {, Ӧ-17, Ö-19, Ö-21, Ö-24, Ӧ-25 }\end{array}$ \\
\hline Kitaptan bakıyorum & 2 & Ö-9, Ö-11 \\
\hline Yardım alıyorum (hoca, arkadaş, aile vs.) & 12 & $\begin{array}{l}\text { Ö-9, Ö-10, Ö-11, Ö-12, Ö-13, Ö- } \\
\text { 19, Ö-20, Ö-21, Ö-23, Ö-24, Ö- } \\
\text { 26, Ö-27 }\end{array}$ \\
\hline Bırakıyorum & 1 & Ö-23 \\
\hline
\end{tabular}

Tablo 12, Türkçe öğrenen Suriyeli öğrencilerin yazma çalışmaları esnasında zorlandıklarında yazma çalışmalarını bırakma, çalışmalardan soğuma veya sıkılma gibi olumsuz tutumlar sergilememekte olduğunu tersine çalışmalarını tamamlayabilmek için çeşitli kaynaklardan yardım aldıklarını göstermektedir. Türkçe bilen birinden yardım almak, internetten faydalanmak, sözlüğe bakmak gibi cevaplarla öğrenciler Türkçe öğrenmeye ve Türkçe yazı yazmaya karşı yüksek güdüye sahip olduklarını da göstermektedirler. Zorlukla karşılaştığında ise yazma çalışmalarını bıraktığını belirten öğrenci sayısı ise 1'dir. Duruma ilişkin öğrenci görüşlerinden bazıları şöyledir:

Sözlükten baklyorum (Ö-1)

Internetten çevirir sonra yazarım $(\ddot{O}-4)$

Yardım allyorum. Kitap veya arkadaşlarımdan alırım (Ö-9)

Kizlarıma soruyorum (Ö-10)

Gidip kitapları araştırırım anneme ve babama sorarım (Ö-11)

Benim hocam soruyorum bazen Türkçe bilen arkadaşlarım soruyorum (Ö-13)

Öğrencilerin Türkçe öğrenirken en çok zorlandıkları becerilerle ilgili veriler Tablo 13 'te gösterilmiştir.

Tablo 13: Öğrencilerin En Çok Zorlandıkları Becerilere İlişkin Veriler

\begin{tabular}{|c|c|c|}
\hline Madde & Frekans & Öğrenci \\
\hline Yazma & 11 & $\begin{array}{l}\text { Ö-1, Ö-2, Ö-5, Ӧ-6, Ö-10, Ö-12, } \\
\text { Ö-13, Ӧ-18, О-19, Ӧ-24, Ӧ-25 }\end{array}$ \\
\hline Dinleme & 10 & $\begin{array}{l}\text { Ö-7, Ӧ-15, Ӧ-16, Ӧ-19, Ӧ-21, Ö- } \\
\text { 22, Ӧ-23, Ö-24, Ӧ-26, Ӧ-27 }\end{array}$ \\
\hline Konuşma & 7 & $\begin{array}{l}\text { Ö-1, Ö-3, Ö-4, Ö-6, Ö-14, Ö-18, } \\
\text { Ö-20 }\end{array}$ \\
\hline Okuma & - & \\
\hline Dil Bilgisi & 4 & Ö-8, Ö-9, Ö-11, Ö-17 \\
\hline
\end{tabular}

Tablo incelendiğinde, Türkçe öğrenen Suriyeli öğrencilerin en çok zorlandıkları becerinin yazma becerisi olduğu görülmektedir. Bundan sonra sırasılyla dinleme, konuşma ve dil bilgisi gelmektedir. Okuma becerisinde zorlandığını belirten öğrenci ise hiç yoktur. Öğrencilerin en çok zorlandıkları becerinin yazma olması, onların bu beceride kaygı yaşamalarının nedeni olarak görülebilir. $\mathrm{Bu}$ veriler aynı zamanda öğrencilerin bu becerisini geliştirmek ve yaşadıkları zorlukların önüne geçebilmek için çeşitli çalışmalar yapılması gerektiğini de göstermektedir. Maddeye ilişkin öğrenci görüşlerinden bazıları şunlardır: 
En çok zorlandı̆̆ım beceri yazma. Çünkü fazla kelimeleri bilmiyorum (Ö-2)

Yazma çünkü çok düşünmem lazım birde cümleler nasıl başlayacağım bilmiyorum

En çok zor konuşma. Benim konuşma çok zaylf. Çünkü ailemle oturuyorum ailem hiç Türkçe bilmiyor (Ö-3)

Dinleme becerisi, çünkü Türkler hızlı konuşurlar (Ö-7)

En zorlandığımız şey dinlemedir. Çünkü sesli harfler çok birbirine benziyor (Ö-16)

Dil bilgisi. Çünkü kuralları hep karıştırıyorum (Ö-9)

Türkçe öğrenen Suriyeli öğrencilerin yazma becerisinin geliştirilmesine yönelik görüşlerine ilişkin veriler Tablo 14'te verilmiştir.

Tablo 14: Suriyeli Öğrencilerin Yazma Becerisinin Gelişimine Yönelik Görüşlerine İliş̧kin Veriler

\begin{tabular}{lcl}
\hline \multicolumn{2}{l}{ Yazma Becerinizi Geliştirmek İçin Neler Yapmanız Gerekir? } \\
\hline Madde & Frekans & Öğrenci \\
\hline Okumalıyım & 5 & Ö-1, Ö-2, Ö-5, Ö-8, Ö-27 \\
Kelime öğrenmeliyim & 6 & Ö-2, Ö-3, Ö-4, Ö-8, Ö-15, Ö-16 \\
Yazmalıyım & 11 & Ö-3, Ö-4, Ö-5, Ö-7, Ö-12, Ö-13, \\
& & Ö-19, Ö-22, Ö-23, Ö-25, Ö-27 \\
Çok çalışmalıyım & 3 & Ö-18, Ö-24, Ö-25 \\
\hline
\end{tabular}

Tablo 14'te yazma becerisinin geliştirilebilmesi için neler yapılabileceğine dair öğrenci görüşlerine yer verilmiştir. Buna göre öğrencilerin en çok yazma çalışması yaparak bu becerinin geliştirilebileceğini, diğer kısmının ise kelime öğrenerek, okuma çalışması yaparak ve çalışarak yazma becerilerini geliştirebileceklerini belirttiği görülmektedir. Buna yönelik öğrenci görüşlerinden bazıları şunlardır:

Daha fazla Türkçe dinlemem lazım, kitap okumam lazım (Ö-1)

Çok kitap okumam gerekiyordu veye çok kelimeler öğrenmem lazım (Ö-2)

Ben her akşam metinler yazıyorum (Ö-3)

Kelimeler ezberlemeliyim $(\ddot{O}-4)$

Her gün kitap okumamaya çalışın ve kelimeler hazırlayın ve ezberleyin (Ö-8)

Çok çalışmak lazım (Ö-18)

Ne kadar çok okursanız yazınız o kadar güçlü olur. Ve yazmaya çalışırsanız iyi olur.

$(\ddot{O}-27)$

Nicel verilerden elde edilen sonuçlara ve öğrenci görüşlerine bakıldığında genel olarak öğrencilerin yüksek yazma kaygısı taşımadıkları ve Türkçe yazma çalışmalarına karşı olumlu tutum sergiledikleri gözlemlenmektedir.

\section{Sonuç ve Tartışma}

Türkçe öğrenen Suriyeli öğrencilerin yazma kaygılarını çeşitli değişkenler açısından incelemeyi amaçlayan bu çalışmada öğrencilerin yazma kaygısı düzeylerini ortaya çıkarmak amaçlı analizler yapılmıştır. Bu kapsamda öğrencilere Şen ve Boylu (2017) tarafından geliştirilen "Türkçeyi Yabancı Dil Olarak Öğrenenlere Yönelik Yazma Kaygısı Ölçeği” ve Öğrenci Görüşme Formu uygulanmıştır.

Yapılan analizler sonucunda öğrencilerin cinsiyet, Türkçeye bakış açıları, ders dışı Türkçe yazma çalışmaları yapma durumları, Türkiye'de geçirdikleri süre, İnternet sitelerinde kullandıkları dil, 
e-posta yazarken kullandıkları dil ve cep telefonunda mesaj yazarken kullandıkları dil değişkenlerine göre yazma kaygıları açısından anlamlı bir farklılığın olmadığı ortaya çıkmıştır. Alanda yapılan Türkçenin ister ana dili olarak öğretilmesi ister yabancı dil olarak öğretilmesiyle ilgili diğer çalışmalar (Karakaya ve Ülper, 2011; İşeri ve Ünal, 2012; Maden vd., 2015; Karahan, 2017) incelendiğinde de öğrencilerin cinsiyet değişkenine bağlı olarak yazma kaygıları açısından anlamlı bir farklılık göstermediği görülebilmektedir.

Öğrencilerin ders dışı Türkçe yazma çalışmaları yapma durumları değişkenleri açısından da yazma kaygısında anlamlı bir farklılığın olmadığı ortaya çıkmıştır. Aslında bu değişkenin yazma kaygısı üzerinde etkili olması beklenmektedir. Zira yapılan çalışmalar da bunu destekler niteliktedir. İşeri ve Ünal (2012) hazırladıkları çalışmada, çalışma gruplarının yazma sıklıkları arttıkça yazma kaygılarının düştügünü; Güneyli (2016) de günlük, öykü, deneme ve şiir yazan bireylerin, yazmayan bireylere oranla, daha düşük yazma kaygısına sahip olduklarını tespit etmiştir. Bu çalışmada ise yazma ders dışı yazma çalışması yapan öğrencilerle yapmayan öğrenciler arasında anlamlı bir farklılık tespit edilememiştir. $\mathrm{Bu}$ durumun nedeni olarak öğrencilerin ders dışı yazma çalışmalarını gönüllü olarak yapmamaları gösterilebilir. Çünkü öğrencilerin ders dışı Türkçe yazma çalışmalarının neredeyse tamamı ödev yapmak şeklindedir. Ödevleri de zorunlu birer unsur olarak görmeleri ve bunları gönüllü olarak değil de zorunlu olarak yapmaları, yazma kaygısını düşürmede bir etki gösterememektedir.

Yabancı dil öğrenmede, bu öğrenme sürecinin nerede gerçekleştiği de önemli bir unsurdur. Hedef dilin konuşulduğu bölgelerde gerçekleştirilen eğitimin, öğrenmeyi olumlu etkilemesi gerekmektedir. Ancak çalışmanın araştırma konularından biri olan "Öğrencilerin Türkiye'de geçirdikleri süre" değişkeni, beklenen bu etkiyi vermemiştir. Elde edilen sonuçlar incelendiğinde, öğrencilerin Türkiye'de geçirdikleri sürenin yazma kaygısını etkilemediği görülmektedir. Bu durumun nedeni olarak da öğrencilerin yaşadıkları çevrenin Türkçe konuşmayı gerektirmemesi verilebilir. Yoğun bir Suriyeli nüfusun içinde yaşayan öğrenciler Türkçe konuşmaya ihtiyaç duymamaktadırlar. Hatta çevrelerindeki insanların çoğunun Türkçe bilmemesi, onları ana dillerini konuşmak zorunda bırakmaktadır. Bu durumda da yaşanılan süre hem Türkçe öğrenmede hem de kaygılarını yok etmede yeterli etkiyi gösterememektedir.

Yaş değişkeninin yazma kaygısı üzerindeki etkisi incelendiğinde de öğrencilerden 25 yaş ve üzerinde olanların, daha küçük olanlara göre daha fazla kaygı taşıdıkları görülebilmektedir. Bunun sebebi olarak da iki durum gösterilebilir: Birincisi, küçük yaşta olanların lise eğitimlerini de Türkiye'de almış olmaları ve Türkçe ile daha fazla muhatap olmaları onların daha az kaygı duymalarını sağlamıştır. İkinci sebep olarak da yaşı büyük olan öğrencilerin hayata yönelik (iş, eğitim vb.) kaygılarının daha yüksek olması gösterilebilir.

Türkçe dergi, kitap ve gazete okuma durumları değişkeni incelendiğinde de okuma yapan öğrencilerin yapmayanlara göre daha az kaygı duydukları tespit edilmişti. Bu sonuç literatürdeki diğer çalışmalardan elde edilen sonuçlarla da örtüşmektedir. Güneyli (2016) yaptığı çalışmada, okuma yapan öğrencilerin yapmayanlara göre daha az yazma kaygısı yaşadıklarını, Yıldız ve Ceyhan (2016) da öğrencilerin okuma kaygılarıyla yazma kaygıları arasında pozitif yönlü bir ilişki olduğunu ortaya çıkarmışlardır.

Yapılan çalışma genel olarak incelendiğinde ise Türkçe öğrenen Suriyeli öğrencilerin yazma kaygılarının yüksek olmadığının ortaya çıktığı söylenebilir $(\bar{X}=42,36)$. Öğrencilerden yazma becerilerine yönelik görüşlerinin toplandığı Öğrenci Görüşme Formu ile elde edilen veriler de bu sonucu destekler niteliktedir. Formdan elde edilen verilere göre öğrencilerin büyük kısmının Türkçe yazı yazdığında mutlu olduğu ve kendilerini rahat hissettikleri, yazma esnasında zorlandıklarında çalışmayı bırakmayıp yardım aldıkları ve güzel ve anlaşılır bir şekilde Türkçe kompozisyon yazabileceklerine inandıkları sonucuna ulaşılmıştır. Bu sonuçlar öğrencilerin yüksek kaygı düzeyine sahip olmadıklarını göstermektedir. 
Öğrenciler her ne kadar yüksek oranda yazma kaygısı taşımadıklarını belirtseler de en çok zorlandıkları becerinin yazma becerisi olduğunu da belirtmişlerdir. Bu nedenle yazma becerisini geliştirilmesi ve öğrencilerin bu beceride istenilen düzeye ulaşabilmesi için bu beceriye gerekli önemin verilmesi ve öğrencileri geliştirici etkinliklerin gerçekleştirilmesi gerektiği sonucu ortaya çıkmaktadır.

\section{KAYNAKÇA}

Açık, F. (2008).Türkiye'de yabancılara Türkçe öğretilirken karşılaşılan sorunlar ve çözüm önerileri. Doğu Akdeniz Üniversitesi Eğitim Fakültesi Türkçe Eğitimi Bölümü Uluslararası Türkçe Eğitimi ve Öğretimi Sempozyumu.

Alan, Y. (2019). 4+1 planl yazma ve değerlendirme modelinin Türkçeyi yabancı dil olarak ögrenen öğrencilerin yazma becerilerine ve bağdaşılklk araçlarını kullanma düzeylerine etkisi. Yayımlanmamış doktora tezi. Hatay Mustafa Kemal Üniversitesi Sosyal Bilimler Enstitüsü.

Bağc1, H. ve Başar, U. (2013). Yazma eğitimi. (ed. Mustafa Durmuş ve Alparslan Okur). Yabancılara Türkçe öğretimi el kitabı. Ankara: Grafiker Yayınları.

Büyükikiz, K. K. (2012). Türkçeyi ikinci dil olarak öğrenen yabancılar için yazma becerisi öz yeterlilik ölçeğinin geliştirilmesi: geçerlilik ve güvenilirlik çalışması. Mustafa Kemal Üniversitesi Sosyal Bilimler Enstitüsü Dergisi, 9(12), 69-80.

Büyüköztürk, Ş.; Çakmak, E. B.; Akgün, Ö. E.; Karadeniz, Ş. ve Demirel, F. (2008). Bilimsel araştırma yöntemleri. Ankara: Pegem Akademi Yayınları.

Creswell, J. W. (2013). Qualitative inquiry \& research design: choosing among five approaches (3rd ed.). Thousand Oaks, CA: SAGE.

Demirel, Ö. ve Şahinel, M. (2006). Türkçe ve sınıf ögretmenleri için Türkçe ögrretimi (7. Bask1). Ankara: Pegem Akademi.

Er, O., Biçer, N. ve Bozkırlı, K. Ç. (2012). Yabancılara Türkçe öğretiminde karşılaşıllan sorunların ilgili alan yazını 1şı̆̆ında değerlendirilmesi. Uluslararası Türkçe Edebiyat Kültür Eğitim (TEKE) Dergisi, 1(2), 51-69.

Erol, H. F. (2016). Yabancı dil olarak Türkçe ögretiminde yazma becerisi. (ed. Faruk Yıldırım ve Burak Tüfekçioğlu). Yabancı dil olarak Türkçe öğretimi kuramlar-yöntemler-beceriler-uygulamalar. Ankara: Pegem Akademi Yayınları.

Göçer, A. (2016). Yazma eğitimi. Ankara: Pegem Akademi Yayıncılık.

Güneyli, A. (2016). Kıbrıslı Türk öğrencilerin yazma kaygısı düzeylerinin incelenmesi. Eğitim ve Bilim, 4l(183), 163-180.

İşeri, K. ve Ünal, E. (2012). Türkçe öğretmen adaylarının yazma kaygı durumlarının çeşitli değişkenler açısından incelenmesi. Mersin Üniversitesi Eğitim Fakültesi Dergisi, 8(2), 67-76.

Karakaya, İ. ve Ülper, H. (2011). Yazma kaygısı ölçeğinin geliştirilmesi ve yazma kaygısının çeşitli değişkenlere göre incelenmesi. Kuram ve Uygulamada Eğitim Bilimleri, 11(2), 691-707.

Karakuş Tayşi, E. ve Taşkın, Y. (2018). Ortaokul öğrencileri için yazma kaygısı ölçeğinin geliştirilmesi: geçerlik ve güvenirlik çalışması. Uluslararası Türkçe Edebiyat Kültür Eğitim Dergisi, 7(2), 1172-1189.

Karatay, H. (2011). Süreç temelli yazma modelleri: planlı yazma ve değerlendirme (ed. Murat Özbay). Yazma eğitimi. Ankara: Pegem Akademi Yayıncılık. 
Kılınç, A., Aytan, N. ve Ünlü, S. (2016). Türkçe öğrenen yabancı öğrencilerin yazma kaygılarının çeşitli değişkenlere göre incelenmesi. Turkısh Studies International Periodical for the Languages, Literature and History of Turkish or Turkic,11(3), 1511-1526.

Kirik, E. (2018). Yabancılara Türkçe öğretiminde karşılaşılan sorunlar üzerine tespitler ve teklifler: Sudan -Kur'an-ı Kerim ve İslamî Bilimler Üniversitesi örneği. (ed. Osman Köse, Esra Kirik). Bilimsel araştırmalarda yeni yaklaşımlar -1 içinde. Ankara: Berikan Yayınevi

Maden, S.; Dinçel, Ö. ve Maden, A. (2015). Türkçeyi yabancı dil olarak öğrenenlerin yazma kaygıları. Uluslararası Türkçe Edebiyat Kültür Ĕ̈itim Dergisi Sayı: 4(2), 748-769.

Merriam, S. B. (2013). Nitel araştırma desen ve uygulama için bir rehber. (Çev.Editörü: Selahattin Turan). Ankara: Nobel Yayinları.

Özdemir, B. ve ÖzbaY, M. (2016). 6+1 analitik yazma ve değerlendirme modelinin Türkçe öğretmeni adaylarının yazma becerilerine etkisi. Ana Dili Ĕgitimi Dergisi, 4(2), 261-276.

Polatcan, F. (2019). Yabancı dil olarak Türkçe öğretiminde kayg1 üzerine yapılan araştırmaların incelenmesi. Ana Dili Eğitimi Dergisi, 7(1), 205-216.

Reeves, L.L. (1997). Minimizing writing apprehension in the learner-centered classroom. English Journal, 86(6), 38-45.

Şen, Ü. ve Boylu, E.(2017). Türkçeyi yabancı dil olarak öğrenenlere yönelik yazma kaygısı ölçeğinin geliştirilmesi. Uluslararası Türkçe Edebiyat Kültür Eğitim Dergisi, 6(2), 1122-1132.

Tekindal, S. (2009).Duyuşsal özelliklerin ölçülmesi için araç oluşturma. Ankara: Pegem Akademi Yayıncilik.

Tiryaki, E. N. (2012). Üniversite öğrencilerinin yazma kaygısının çeşitli değişkenler açısından belirlenmesi. Dil ve Edebiyat Eğitimi Dergisi,1(1), 14-21.

Ürün Karahan, B. (2017). Türkçe öğretmeni adaylarının yazma kaygıları ile yazma alışkanlıkları arasındaki ilişki. Insan ve Toplum Bilimleri Araştırmaları Dergisi, 6(5), 3065-3075

Yaman, H. (2010). Türk öğrencilerinin yazma kaygısı: ölçek geliştirme ve çeşitli değişkenler açısından yordama çalışması. International Online Journal of Educational Sciences, 2(1), 267-89.

Yıldırım, A. ve Şimşek, H. (2016). Sosyal bilimlerde nitel araştırma yöntemleri (10. Bask1) Ankara: Seçkin Yayınevi.

Yıldız, M. ve Ceyhan, S. (2016) İlkokul 4. sınıf öğrencilerinin okuma ve yazma kaygılarının çeşitli değişkenler açısından incelenmesi. Turkısh Studies International Periodical for the Languages, Literature and History of Turkish or Turkic, 11(2), 1301-1316.

Zorbaz, K. Z. (2011). Yazma kaygısı ve yazma kaygısının ölçülmesi. E-Journal of New World Sciences Academy, 6(3), 2271-2280. 